\title{
KONSEP GANTI RUGI PERSPEKTIF HUKUM ISLAM
}

\author{
Jaya Miharja \\ IAI Nurul Hakim Lombk Barat
}

\begin{abstract}
Abstrak
Ganti rugi terhadap korban perdata maupun pidana, sejak awal sudah disebutkan oleh nas al-Qur'an maupun Hadis Nabi. Dari nas-nas tersebut para ulama merumuskan berbagai kaidah fiqh yang berhubungan dengan dhaman atau ganti rugi. Memang diakui sejak awal, para fuqaha tidak menggunakan istilah masuliyah madaniyah sebagai sebutan tanggung jawab perdata, dan juga masuliyah al-jina'iyah untuk sebutan tanggung jawab pidana. Namun demikian sejumlah pemikir hukum Islam klasik terutama al-Qurafi dan al-'Iz Ibn Abdi Salam memperkenalkan istilah al-jawabir untuk sebutan ganti rugi perdata (baca:dhaman), dan al-zawajir untuk sebutan ganti rugi pidana (baca: "uqubah diyat, arusy dan lain-lain).Walaupun dalam perkembangannya kemudian terutama era kekinian para fuqaha' sering menggunakan istilah masuliyah yang tidak lain merupakan pengaruh dari karya-karya tentang hukum Barat. Dhaman dapat terjadi karena penyimpangan terhadap akad dan disebut dhaman al-aqdi, dan dapat pula terjadi akibat pelanggran yang disebut dhaman 'udwan. Di dalam menetapkan ganti rugi unsur-unsur yang paling penting adalah darar atau kerugian pada korban. Darar dapat terjadi pada fisik, harta atau barang, jasa dan juga kerusakan yang bersifat moral dan perasaan atau disebut dengan darar adabi termasuk di dalamnya pencemaran nama baik.Tolok ukur ganti rugi baik kualitas maupun kuantitas sepadan dengan darar yang diderita pihak korban, walaupun dalam kasus-kasus tertentu pelipatgandaan ganti rugi dapat dilakukan sesuai dengat kondisi pelaku.
\end{abstract}

Kata Kunci: Ganti rugi, Hukum Islam

\section{A. PENDAHULUAN}

Secara umum, hukum Islam secara kualitatif maupun kuantitatif melindungi kemaslahatan setiap individu di tengah masyarakat. Perlindungan tersebut meliputi aspek agama, jiwa, keturunan, akal, dan harta. Semua orang diwajibkan untuk menghormati kelima hak tersebut dan bekerja secara sungguh-sungguh untuk memeliharanya. Dalam konteks ini Al-Qur'an menjelaskan bahwa man qotala nafsan bigairi nafsin awu fasâdin fi al-ardh fakaannamâ qotala al-nâsa jamz'a, juga man qotala mu'minan khotho'an fatahrzru roqobatin mu'minatin wa diyyatun musallamah ilâ ahlihi. 
Al-Qur'an juga mewajibkan berlaku adil dalam bermuamalah dan berlaku ihsân kepada kerabat, tetangga, dan umat Islam secara keseluruhan. Al-Qur'an melarang makan harta orang lain dengan cara batil, mewajibkan qisas terhadap pelaku pembunuhan yang zalim untuk menghilangkan darar pada korban: wa jaz al-'u sayyiatin sayyiatun misluhâ, juga famani' tadâ 'alaikum fa'tadu 'alaihi bi misli mani'tada 'alaikum. Islam juga meletakkan prinsip-prinsip tanggung jawab seseorang terhadap perbuatannya, bukan atas perbuatan orang lain: fakullu nafsin bimâ kasabat rahinah, juga wa likulli insânin ma kasaba wa 'alaihi ma iktasaba, serta walâ taziru wâziratun wizra ukhrâ dan prinsip-prinsip lainnya yang belum dikenal oleh sistem hukum Barat kecuali di zaman modern ini.

Sunnah Nabi pun muncul untuk memperkuat makna prinsip pertanggungjawaban tersebut. Ditegaskan oleh Nabi Muhammad bahwa al-muslim akhu al-muslim la yazlimuhu wala yakhzuluhu. Sunah Nabi juga meletakkan pondasi kaidahkaidah umum yang bertujuan untuk menghilangkan darar secara mutlak seperti disebutkan oleh hadis Nabi Lâ darara walâ diroro. Pada saat haji wada' (haji perpisahan) Nabi juga menegaskan dasar-dasar umum untuk kehidupan sosial yang anggun dan bermartabat. Pada saat-saat terakhir kehidupan Muhammad, beliau mewajibkan dhaman (ganti rugi) pada perbuatan yang berlatar belakang ta'addi (pelanggaran terhadap hukum) pada amwal (harta), al-mumtalikat (hak milik), Nabi menegaskan "ala al-yadi ma akhazat hatta tarudduhu”.

Bertitik tolak dari prinsipprinsip umum tersebut di atas, para fuqaha' memformulasikan kaidahkaidah pertanggungjawaban (qawa'id al-masûliyah). Mereka melakukan identifikasi mana yang masuk dalam kategori khitab al-taklif al-jina'i (pidana) yang berimplikasi pada al'uqubah (hukuman) terhadap pelaku (mukholafatu awâmir al-syari' wa ahkâmihi), dengan al-taklif bi dhaman (beban ganti rugi). Dalam hubungan inilah al-Qurafi dan 'Izzuddin Ibn Abdi al-Salam masing-masing dalam karya mereka al-Furuq dan al-Qawa'id alAhkam menegaskan dan menjelaskan secara konkret perbedaan antara alawajir atau al-'uqubat dengan al-jawabir atau dhamanat. ${ }^{1}$

${ }^{1}$ Kenyataan ini kemudian menyimpan pe tanyaan akan sumber perundang-undangan Barat yang sesungguhnya ketika membedakan antara almasuliyah al-jinaiyah (tanggung jawab pidana) dan al-masuliyah al-madaniyah (tanggung jawab perdata), dan antara al-masuliyah al-taqshiriyah (tanggung jawab akibat kecerobohan dan kelalaian) dan al-masuliyah al-aqdiyah (tanggung jawab akibat pelanggaran perjanjian kontrak). Adalah sangat tidak mungkin model pembagian ini tanpa dipengaruhi oleh sistem hukum Islam.

Meski demikian al-Sanhuri berkeyakinan bahwa sistem hukum Perancis adalah paling awal dalam menjelaskan masuliyah dan macammacamnya dengan melakukan interpretasi terhadap hukum Romawi. Padahal hukum Romawi tidak melakukan pembagian al-masuliyah secara rinci seperti itu. Inilah yang ditegaskan oleh Sayyid Abdullah Husain ketika menolak pendapat Sanhuri dengan menyatakan: "Pengambilan atau penyaduran dari mazhab Malik bukan dimulai pada tahun 1805, melainkan sejak tahun $200 \mathrm{H}$. Ketika Islam menguasai Eropa, Andalusia menjadi pusat ilmu pengetahuan, pada saat Eropa secara umum berada dalam kegelapan intelektual." Pada saat itu 
Kaidah-kaidah universal yang menjadi teori umum dhaman antara lain adalah ${ }^{2}$ :

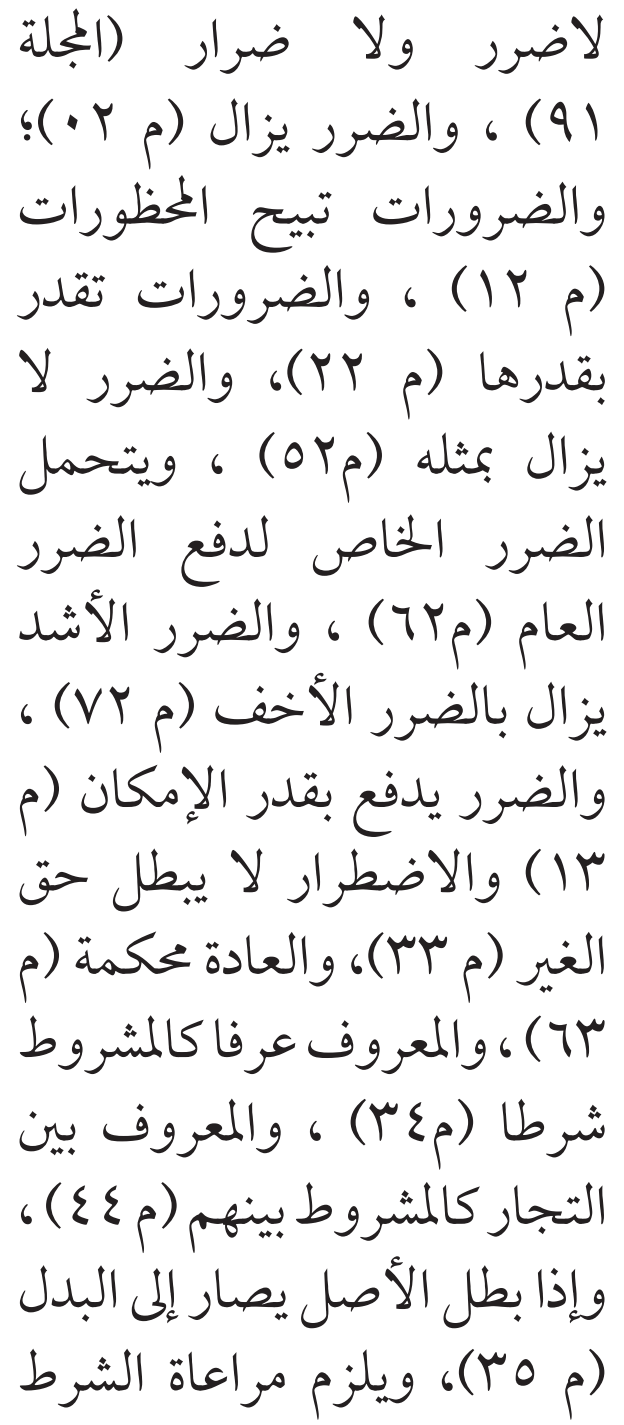

Islam masuk daratan Eropa dan memerintah penduduknya serta membangun kaidah-kaidah hukum yang adil. Penduduk Eropa berdatangan ke Andalusia semata-mata untuk menimba ilmu pengetahuan. Abdullah Husain juga berpendapat bahwa hukum perdata Perancis yang menjadi sumber berbagai hukum saat ini adalah terambil dari mazhab Malik ibn Anas. Lihat Sayyid Abdullah Husain, "al-Muqaranât al-Tasyri'iyah", dalam Muhammad Ahmad Siraj, Dhaman al- 'Udwan fi al-Fiqh al-Islami (Dirâsah Fiqhiyah Muqâranah bi ahkâm al-masuliyah al-Taqshiriyah fi al-qanun), al-Muassasah al-Jami'iyyah li al-Dirâsat wa al-Nasyr wa al-Tauzi', hal. 15.

${ }^{2}$ Mustofa Ahmad al-Zarqa', al-Madkhal alFiqhial-'Am (al-Fiqhal-Islamifi Saubihial-Jadid), Beirut: Dar al-Fikr.

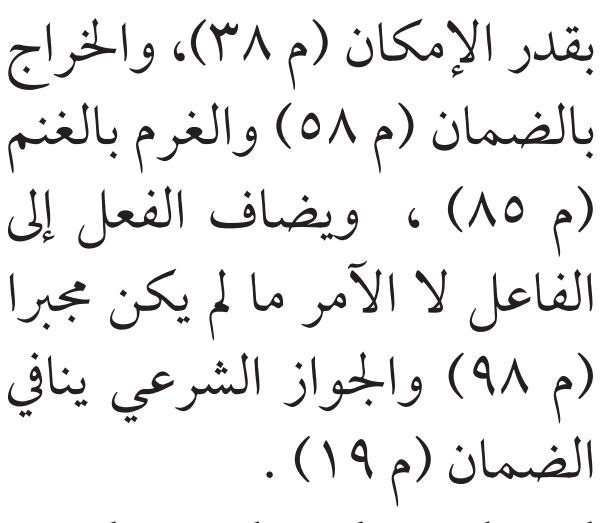

Demikian pula pada pasal-pasal lain dalamal-Majallah. Hukum-hukum yang berkaitan dengan perampasan (al-gasb), misalnya, dimuat dalam pasal 890-912. hukum-hukum yang berkaitan dengan perusakan barang (itlâf) dimuat dalam pasal 912-942.

Tulisan ini tidak bermaksud melakukan perbandingan antara teori dhaman menurut fiqh dan hukum, apalagi melakukan kajian terhadap pengaruh hukum fiqh terhadap sistem hukum Barat terutama hukum Perancis. Tulisan ini hendak mengemukakan teori dhaman secara umum dan sebagian aplikasinya terhadap tanggung jawab seseorang atas perbuatannya.

\section{B. PENGERTIAN DHAMAN 13}

Dalam term fiqh, dhaman juga dimaknai beragam. ${ }^{3}$ Imam Ghazali, ${ }^{4}$ misalnya memaknai dhaman dengan 'luzumu rad al-syayy' awu badaluhu

${ }^{3}$ Definisi dhaman yang beragam mengarah pada makna menjamin (menanggung) untuk membayar utang, mengadakan barang, atau menghadirkan orang pada tempat yang telah ditentukan. Karena itu, biasanya dhaman mengandung tiga masalah pokok, yaitu (1) jaminan atas utang seseorang; (2) jaminan dalam pengadaan barang; dan (3) jaminan dalam menghadirkan seseorang di tempat tertentu, seperti pengadilan.

${ }^{4}$ al-Gazali, al-Wajiz, hal. I/ 208. 
bil mitsli awu bil qimati (keharusan mengganti suatu barang dengan barangyangsama atau sepadan dengan nilai jualnya). Al-Hamawy ${ }^{5}$ pensyarah kitab al-Asybah wa al-Naza' ir karya Ibn Nujaim mengatakan bahwa dhaman adalah 'ibâratun 'an raddi misli al-hâlik awu qimatuhu (mengganti barang yang rusak dengan barang yang sama atau yang sepadan dengan nilai jualnya). Sedangkan as-Syaukani ${ }^{6}$ mengatakan bahwa dhaman adalah 'ibaratun 'an garamati al-tâlif (mengganti barang yang rusak).

Majallah al-Ahkam al-Adliyah ${ }^{7}$ menyebutkan bahwa ganti rugi disesuiakan dengan jenis barang yang rusak (dhaman huwa i'tha'u misli alsyai' inkâna minal misliyât, waqimatuhu inkâna minal qimiyât). Apabila jenisnya tergolong al-misliyât, maka ganti ruginya dengan barang yang sama (al-misli). Jika barang yang rusak tergolong al-qimiyât, maka nilai ganti rugi disesuaikan dengan nilai jualnya di pasar (qimah). ${ }^{8}$ Menurut al-Zarqa ${ }^{9}$ dhaman adalah iltizâm bi ta'widhin maliyin 'an darari al-gair. Sedangkan menurut al-Zuhaili dhaman adalah hua al-iltizâm bita'widhi al-gair 'amma lahiqahu min talafi al-mal awu dhiyâ' almanâfi', awu ishabatin min dhararin juz'i

${ }^{5}$ Ahmad Ibn Muhammad al-Hamawy, Gamzu 'Uyûni al-Basha'ir wa Syarah al-Asybâh wa al-Nâza'ir, Bairut: Dar al-Kutub al-ilmiah, Cet. 1405 H/1985 M, hal. 2/211.

${ }^{6}$ As-Syaukani, Nail al-Authar Syarh Muntaqa al-Akhbar, Mesir: Mustafa al-Babi al-Halabi, $1380 \mathrm{H}$, hal. 5/299.

${ }^{7}$ Atasi, Syarah Majallatu al-Ahkam al-Adliyah, dicetak di Hims Suriah, $1352 \mathrm{H}$.

${ }^{8}$ al-Majallah, pasal 416.

'al-Zarqa', al-Madkhal, hal. 1032, pasal 648. awu kulli hâdisun bi al-nafsi al-insâniyah awu bi'udhwin minhâ. ${ }^{10}$

Baik definisi al-Gazali maupun al-Majallah sama-sama membatasi dhaman pada tanggung jawab akibat perbuatan yang tergolong ta'addi seperti merampas atau merusak harta orang lain. Kedua definisi tersebut juga tidak menyentuh dhaman al-aqdi (ganti rugi yang muncul akibat pelanggaran akad). Pengertian dhaman seperti ini sudah barang tentu masih kurang karena tidak mengakomodasi seluruh teori dhaman yang sudah dirumuskan oleh para fuqaha'.

Adapun definisi al-Syaukani, al-Zarqa', dan al-Zuhaili sama-sama berangkat dari darar. Darar-lah yang mewajibkan ganti rugi. Berdasarkan titik tolak ini maka dhaman mencakup sesuatu yang wajib pada zimmah untuk menghilangkan darar yang muncul akibat pelanggaran pada akad (mukhalafatu aqdin), melakukan dan atau tidak melakukan perbuatan tertentu sehingga mengakibatkan mafasid. Al-Bazdawi mengisyaratkan dua macam dhaman, yaitu dhaman alaqdi fasidan kana awu jaizan yajibu bi altarodhi, wa dhaman al-'udwan ya'tamidu awusofal 'ain' ${ }^{11}$ (ganti rugi akibat pelanggaran terhadap perjanjian dalam akad fasid maupun jaiz (akad sahih) diwajibkan berdasarkan kerelaan masing-masing pihak, dan ganti rugi akibat pelanggaran tersebut mengacu pada sifat-sifat barang).

${ }^{10}$ Wahbah al-Zuhaily, al-Mas'uliyah 'an Fi'li al-Gair, Damaskus: Dar al-Muktabi, Cet. 1, 1416 H/1995 M, hal. 12.

${ }^{11} \mathrm{Al}-\mathrm{Bazdawi,}$ Ushul, hal. 31. 
Hal yang sama juga dilakukan olehal-Sarakhsi.Iamembedakanantara dhaman al-'udwan dengan dhaman alaqdi (ganti rugi akibat pelanggaran dengan ganti rugi berdasarkan akad). ${ }^{12}$ Indikasi perbedaan tersebut juga ditunjukkan oleh al-Suyuthi yang merinci sebab-sebab dhaman menjadi dua yaitu ta'addi dan aqdi. ${ }^{13}$ Cakupan dhaman, dengan demikian, meliputi wilayah perdata dan pidana. Sehingga ganti rugi dapat terjadi atas barang yang rusak atau manfaat barang yang hilang, atau luka fisik seseorang sehingga mengakibatkan kerugian, baik total atau sebagian.

Dari catatan tersebut dapat disimpulkan bahwa dhaman adalah tanggungan seseorang untuk memenuhi hak yang berkaitan dengan kehartabendaan, fisik, maupun perasaan seperti pencemaran nama baik. Hal ini berlaku baik darar yang muncul akibat pelanggaran seluruh dan atau sebagian perjanjian dalam akad, melakukan perbuatan (yang diharamkan) dan atau tidak melakukan perbuatan yang (diwajibkan) oleh pembuat undang-undang. Dengan demikian definisi ini mencakup makna-makna sebagai berikut:

1. Obyek wajib dhaman terletak pada zimmah (perjanjian). Kewajiban dhaman tidak akan gugur kecuali dengan memenuhi atau dibebaskan oleh pihak yang berhak menerima ganti rugi

${ }^{12}$ Al-Sarakhsi, al-Mabsut, Mesir: al-Sa'adah, $1324 \mathrm{H}$, hal 11/ 69 .

${ }^{13}$ Jalaluddin Al-Suyuthi, al-Asybah wa alNaza'ir, Beirut: Muassasah al-Kutub al-Saqofiyah, Cet. 1, 1415 H/ 1994 M, hal. 362. tersebut. Pihak yang dirugikan (mutadarrar)berhakmengadukan mutasabbib (penyebab kerugian) ke pengadilan agar memenuhi kewajibannya. Berbeda dengan kewajiban yang bersifat moral atau keagamaan, syari' hanya mendoronguntukmemenuhinya tanpa implikasi hukuman keduniaan karena merupakan khitab al-targib yang meliputi makruhat dan mandubat. Zimmah menurut bahasa adalah al-'ahdu (perjanjian). Menurut tradisi fuqaha' zimmah adalah suatu sifat yang menjadikan seseorang mempunyai kompetensi untuk menerima hak atau melakukan kewajiban. Ahlu zimmah adalah mereka yang melakukan perjanjian di mana dengan perjanjian itu mereka memiliki hak dan kewajiban.

2. Kewajiban atas dasar dhaman berbeda dengan kewajiban atas dasar 'uqubah, baik pada karakter maupun tujuannya. Dhaman ditetapkan untuk melindungi hak-hak individu. Sedangkan 'uqubah ditetapkan karena adanya unsur pelanggaran terhadap hak-hak Allah SWT. Kewajiban pada dhaman bertujuan untuk mengganti atau menutupi (al-jabru) kerugian pada korban. Sementara 'uqubah ditetapkan untuk menghukum pelaku kejahatan agar jera dan tidak melakukan perbuatan itu lagi (al-zajru). Jadi tujuan yang berorientasi pada al-jabru disebut 
dhaman. Sedangkan tujuan yang berorientasi pada al-zajru disebut 'uqubah.

3. Sebab-sebab dhaman adalah adanya unsur ta'addi, yaitu melakukan perbuatan terlarang dan atau tidak melakukan kewajiban menurut hukum. Ta'addi dapat terjadi karena melanggar perjanjian dalam akad yang semestinya harus dipenuhi. Misalnya, penerima titipan barang (al-muda)' tidak memeliharabarang sebagaimana mestinya, seorang al-ajir (buruh upahan, orang sewaan) dangan al-musta'jir (penyewa) samasama tidak komitmen terhadap akad yang mereka sepakati. Ta'addi juga dapat terjadi karena melanggar hukum syariah (mukhalafatu ahkâm syari'ah) seperti pada kasus perusakan barang( al-itlâf), perampasan (al-gasb), maupun kelalaian atau penyia-nyiaan barang secara sengaja (al-ihmâl).

4. Ta'addiyangmewajibkan dhaman benar-benar menimbulkan darar (kerugian). Jika tidak menimbulkan kerugian, maka tidak ada dhaman, karena secara faktual tidak ada darar yang harus digantirugikan. Itulah sebabnya jika seorang pengendara yang lalai menabrak barang orang lain tetapi tidak menimbulkan kerusakan, tidak wajib memberikan dhaman. Namun demikian, terdapat suatu perbuatan dengan sendirinya mewajibkan dhaman seperti al-gasbu (perampasan). Menurut jumhur ulama, pelaku perampasan harus mengganti manfaat barang selama berada dalam penguasaannya walaupun tidak difungsikan. Pendapat ini berdasarkan asumsi bahwa kerugian selalu terjadi pada kasus-kasus perampasan. Kerugian atau darar juga akan dialami oleh orang-orang yang dibatasi kebebasannya oleh penguasa atau seseorang yang ditahan secara ilegal menurut fuqaha' Hanabilah. Pendapat ini memperkuat kaidah bahwa aldharar syarthun liwujubi dhaman (kerugian adalah syarat terhadap keharusan ganti rugi).

5. Antara ta'addi (pelanggaran) dengan darar (kerugian) harus memiliki hubungan kausalitas. Artinya, darar dapat dinisbatkan kepada pelaku pelanggaran secara langsung. Jika darar dinisbatkan kepada sebab-sebab lain, bukan perbuatan pelaku (muta'addi) sendiri, maka dhaman tidak dapat diberlakukan, karena seseorang tidak dapat dibebani tanggung jawab atas akibat perbuatan orang lain. Kaidah syariah mengenai masalah ini adalah:

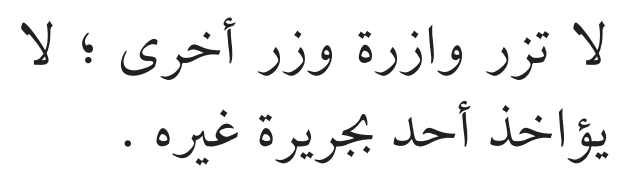

6. Darar harus bersifat umum sesuai dengan keumuman hadis Nabi: laa dharara wa laa dhirara (tidak boleh merugikan diri 
sendiri dan merugikan orang lain). Tingkat darar diukur berdasarkan 'urf(kebiasaan) yang berlaku. Hal ini sejalan dengan kaidah ushul: yajibu hamlu allafzi 'ala ma'nahu al-muhaddad $f i$ as-syar'i in wujida, wa illa wajaba hamluhu 'ala ma'nahu al-'urfi (suatu keharusan membawa kata kepada maknanya yang definitif secara syara' jika ditemukan, tetapi kalau tidak ada, maka dialihkan kepada makna definitif berdasarkan 'urf). Karena syari' tidak menetapkan makna darar, sehingga ukurannya, baik kualitas maupun kuantitas, mengacu pada 'urf. Dengan demikian, darar yang diganti rugi berkaitan dengan harta benda, manfaat harta benda, jiwa, dan hak-hak yang berkaitan dengan kehartabendaan jika selaras dengan 'urf yang berlaku di tengah masyarakat.

7. Kualitas dan kuantitas dhaman harus seimbang dengan darar. Hal ini sejalan dengan filosofi dhaman, yaitu untuk mengganti dan menutupi kerugian yang diderita pihak korban, bukan membuat pelakunya agar menjadi jera. Kendati demikian, tujuan ini selalu ada dalam berbagai sanksi, walau hanya bersifat konvensional.

Penetapan makna demikian sejalan dengan makna dhaman ${ }^{14}$ secara

${ }^{14}$ Dasar legalitas dhaman antara lain ayat al-Qur'an: famani'tadâ 'alaikum fa'tadû 'alaihi bimisli mâ i'tadâ 'alaikum"(al-Baqarah: 194); ayat wa bahasa, yakni ganti rugi. Maksud ganti rugi yaitu penggantian kerugian yang dialami seseorang. Pemaknaan seperti ini juga terdapat dalam KUH Perdata pasal 1244 dan 1248.

Dari sini perlu dimengerti bahwa dhaman dapat diterapkan dalam berbagai bidang muamalah, terutama menyangkut jaminan harta benda dan nyawa manusia. Maka dari itu, tidak mengherankan bila alMawardi mengatakan bahwa dhaman dalam pendayagunaan harta benda, tanggungan dalam masalah diyat, jaminan terhadap kekayaan, jaminan terhadap jiwa, dan jaminan terhadap beberapa perserikatan adalah hal yang lumrah terjadi di masyarakat. Dengan demikian, dhaman dapat diterapkan juga dalam masalah jual beli, pinjam meminjam, titipan (al-wadi'ah), jaminan (rahn), kerja patungan (qirad/mudharabah), barang temuan (luqathah), peradilan (qada'), hukuman terhadap pembunuhan

jazâ'u sayyiatin sayyiatun misluhâ(al-Syuro: 40); ayat wa in 'âqabtum fa'âqibû bimisli mâ 'ûqibtum bihi" (alNahl: 126). Adapun di dalam al-Sunnah disebutkan, antara lain hadis, riwayat Anas berkata: Ahdat ba'dhu azwajin nabi SW ilaihi tha'aman fi qush'atin, fadharabat al-qus'ata biyadiha, fa alqat mâ fihâ, faqâla an-nabi SW: tha'amun bitha'amin, wa inâun bi inâin (Riwayat Tirmizi). Juga hadis yang cukup populer Alâ al-yadi mâ akhazat hattâ tuaddihi (Riwayat Ahmad). Hadis lainnya, Inna dimâakum wa amwâlakum 'alaikum haromun kahurmati yaumikum haza, fi syahrikum haza, fi baladikum haza (BukhariMuslim). Ibn Hazam juga mengatakan bahwa yang sahih adalah bahwa harta yang diharamkan tidak ada kewajiban seseorang untuk memberikan ganti rugi terhadapnya, baik di dalam nas ataupun ijma'. Hadis lain yang paling populer adalah lâ dharara wa lâ dhirâra. Imam al-Kasani berkata, "Diwajibkan ganti rugi pada kasus perampasan dan perusakan (al-gashbu wa al-itlaf), karena semua itu mengandung unsur perbuatan i'tidâ' dan idrâr." (Badâ'i, hal. VII/165). 
(qisas), perampasan (gasab), pencurian, dan sebagainya.

\section{SEBAB-SEBAB DHAMAN ${ }^{15}$}

Kaum fuqaha' tidak mendiskusikan rukun dhaman secara sistematis dan terpadu seperti yang dilakukan oleh ahli hukum. Mereka membahasnya secara sporadis di

${ }^{15}$ Seseorang tidak dapat dibebankan ganti rugi kecuali memenuhi dua rukun, yaitu: al-i'tida' dan al-darâr. Al-i'tidâ' adalah melampaui batas yang menurut para fuqaha' mengandung unsur kezaliman, rasa permusuhan, dan melampaui hak. Kriterianya adalah menyimpang dari perilaku normal. Adapun sebab-sebab dhaman ada tiga, yaitu aqad, yad, dan itlâf. Dhaman pada aqad dapat terjadi ketika ada pihak yang melakukan interpretasi terhadap ketentuan eksplisit dari redaksi perjanjian atau makna implisitnya sesuai dengan keadaan dan situasi (al'urf atau al-'âdah) yang berlaku. Sedangkan wadh'u al-yad dapat menjadi sumber ganti rugi baik itu alyad mu'tamanah maupun bukan mu'tamanah. Yad al-mu'tamanah seperti yad al-wâdi' dan al-mudhârib, al-'âmil al-musâqi, al-ajir al-khâs, al-washi 'ala mâl alyatim, hakim dan al-qadhi 'ala sunduq al-aitâm, dan lain-lain. Mereka ini jika melakukan ta'addi (personal abuse case) atau taqshir dibebani/dikenakan ganti rugi. Namun jika tidak ada unsur ta'addi atau taqshir tidak dapat dibebankan ganti rugi karena mereka tergolong al-aydi al-amânah (tangan-tangan amanah). Adapun al-yad gairu al-mu'tamanah yang melakukan sesuatu terhadap harta orang lain tanpa izin dari pemilik seperti pencuri dan perampas, atau dengan seizin pemilik seperti al-yad al-bâa' $i$ ' terhadap barang yang dijual sebelum serah terima, atau al-musytari setelah serah terima barang, dan penyewa hewan tunggangan atau semisalnya jika melakukan $t a^{\prime} a d d i$ terhadap syarat-syarat yang sudah ditentukan atau ketentuan yang sudah biasa berlaku. Mereka ini wajib memberikan ganti rugi terhadap kerusakan barang pada saat berada di tangannya, apapun penyebab kerusakan sekalipun terpaksa seperti bencana alam dan lainnya. Adapun al-itlâf menjadi sebab ganti rugi baik langsung maupun hanya sebagai penyebab. Itlâf biasanya diartikan mendisfungsikan barang. al-Itlâf dibagi dua yaitu al-itlaf al-mubasyir (perusakan langsung), dan al-itlaf bi al-tasabbub (perusakan tidak langsung). (Pembahasan tuntas dapat dilihat dalam al-Kasani, al-Badâ'i' dan dalam Majallatu al-Ahkâm al-'Adliyah pasal 887-888. berbagai tempat, antara lain di dalam kitab-kitab al-furu', kaidahkaidah fiqh, dan kitab ushul al-fiqh. Walau begitu, rukun dhaman sudah tergambar di dalam pemikiran mereka ketika mendiskusikan berbagai kasus hukum fiqh. Dari berbagai konstruksi dan fatwa hukum dalam karya-karya fiqh, dapat disimpulkan bahwa rukun dhaman adalah khatha', dharar, dan sababiyah.

Perbuatan-perbuatan hukum
yang mewajibkan dhaman hampir
tidak terbatas jumlahnya. Tetapi secara akumulatif perbuatanperbuatan tersebut dapat disebut perbuatan gair masyru'ah, atau akhtha' atau ta'ddiyat (delicts, torts, wrongs). Namun untuk memudahkan sistem pertanggungjawaban terhadap akibat perbuatan, maka para ahli hukum pertama-tama melakukan pembagian terhadap perbuatan prespektif motif dan tujuan pelaku menjadi: akhtha' 'amdiyah (intekntional torts) dan akhtha' taqshiriyah atau al-ihmal (negligence).

Di dalam figh, al-akhtha' gair al-'amdiyah dibagi menjadi dua macam yaitu al-khatha' dan mâ jarâ majrâhu. Suatu perbuatan yang menjadi tujuan pelaku, namun tidak menghendaki akibatnya disebut al$k h a t h a$ '. Sedangkan suatu perbuatan dan akibatnya sama-sama tidak dikehendaki oleh pelaku disebut mâ jarâ majrâ al-khatha'. Yang pasti khatha' 'amdi sangat berbahaya sehingga di dalam hukum Baratdengan mengacu kepada istilah hukum Perancis-disebut al-khatha' 
lâ yagtafiru (kesalahan yang tidak dimaafkan). ${ }^{16}$

Perbuat an - perbuat a n mewajibkan dhaman, kata al-Qurafi ${ }^{17}$ adalah dilakukan secara langsung oleh pelaku (al-'udwan bi al-mubâsyir), kemudian karena perbuatannya tersebut mengakibatkan kerusakan (al-tasabbub li al-itlâf) pada harta benda misalnya. Singkatnya, sebab-sebab dhaman adalah al-mubasyir, al-tasabbub, dan al-itlaf. Kerusakan ini tidak mesti menjadi tujuan dari pelaku (qashdu $\left.a l-f a^{\prime} i l\right)$. Karena masing-masing orang bertanggung jawab atas akibat perbuatannya. Prinsip ini sesuai dengan kaidah fiqh: الرضا بالشيء رضا عبا عبا

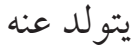

Adapun kesengajaan (al(amd) yang mengakibatkan darar atau kesengajaan untuk melakukan perbuatannamuntidakmengakibatkan darar, tidak menjadi syarat dalam penetapan dhaman. Karena dhaman berkaitan dengan perbuatan hukum dalam lingkup khatha' atau 'udwan bukan pada tujuan perbuatan atau niat pelaku.

Namun demikian, khatha' yang mengharuskan dhaman dibedakan dengan khata' yang mengharuskan 'uqubah serta khatha' al-akhlaqi (kesalahan secara moral) yang hanya berimplikasi pada dosa. Orang tidur menurut teori ini tidak salah secara moral dan juga tidak berdosa. Dengan demikian kalau dia terbolak balik atau jatuh menimpa sesuatu sehingga menimbulkan kerusakan, dia wajib

${ }^{16}$ Siraj, Dhaman, Ibid.

${ }^{17}$ al-Qurafi, al-Furuq, Ibid. melakukan dhaman, tetapi secara etis relegius dia tidak berdosa.

Dhaman tidak terkait dengan al-qasdu dan al-niat. Pendapat ini berdasarkan ijma'. Karena ijma'lah yang mewajibkan dhaman bagi seorang anak yang belum dewasa (alsabiyi), orang gila (al-majnun), orang pelupa (al-nasi), orang tidur (al-naim) dan orang lalai (al-gafil). Dhaman semata-mata terkait dengan al-asbab (adanya sebab akibat). Atau dengan meminjam istilah imam al-Gazali bahwa al-ahliyah (cakap hukum) yang menjadi syarat dalam menetapkan dhaman adalah ahliyatu al-wujub yaitu seseorang dianggap cakap hukum untuk menerima hak, bukan ahliyat al-ada' di mana seseorang dianggap cakap melakukan perbuatan hukum.

Meski sangat jelas bahwa khatha', ihmal, dan taqshir menjadi syarat wajib dhaman, namun tim penyusun al-Majallah al-Ahkam alAdliyah sepertinya mengabaikan prinsip-prinsip umum dhaman. Hal ini terbukti bahwa mereka menetapkan unsur kesengajaan ( $t a^{\prime} a m m u d$ ) sebagai syarat dhaman seperti disebutkan

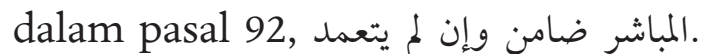
Sedangkan dalam pasal 93 disebutkan: المنسبب لا يضمن إلا بالتعمد

Kemungkinan ada dua faktor yang menyebabkan kekeliruan tersebut.Pertama, mengikutikesalahan yang terdapat dalam karya-karya klasik terutama kitab al-Asybâh karya Ibn Nujaim yang menyebutkan:

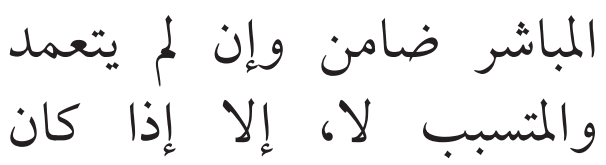




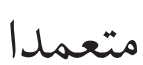

Kedua, ada kemungkinan mengikuti jejak sebagian fuqaha' Hanafiyah generasi awal yang keliru memahami dan menafsirkan mazhab Abu Hanifah yang menetapkan bahwa penyebab kerusakan dibebani ganti rugi (tadhmin mutasabbib). Imam mazhab sendiri tidak melihat tadhmin mutasabbib kecuali ada unsur kesalahan (al-khatha') yang mirip dengan kesengajaan atau suatu kesalahan yang sangat berlebihan sehingga mendekati atau setidaknya mirip dengan kesengajaan.

Terlepas dari apakah ini merupakan kesalahan ilmiah atau kesalahan teknis pengetikan, namun yang pasti kaidah tersebut harus dibaca أن المتسبب لا يضمن (إلا إذا : (كان (كان متعديا Hal ini sesuai dengan kaidah yang ada di dalam Majma' Dhamanat. ${ }^{18}$

Kaum fuqaha' tidak menetapkan syaratbahwa orangyangmenyebabkan (mutasabbib) kerugian harus sudah mumayyiz, atau memiliki al-idrak (pemahaman dan pengetahuan) terhadap kewajiban dhaman. Sehingga seoranganakyang masihusiamumayyiz atau belum, wajib dikenakan dhaman jika melakukan perbuatan yang mengakibatkan kerugian pada orang lan. Demikian pula al-ma'tuh (orang idiot) dan al-majnun (gila). Karena tujuan dari dhaman adalah ganti rugi dengan mal, yang pembayarannya dapat diwakilkan kepada pihak lain.

${ }^{18}$ al-Bagdadi, Majma' al-Dhamanat, Mesir: alKhairiyah, $1388 \mathrm{H}$, hal. 57. رadistentang رفع عن أمتي الخطأو النسيان (diampuni umatku suatu perbuatan karena kelalaian dan kealpaan) tidak menafikan hukum dhaman ketika terjadi al-taqshir (kecerobohan) dan al-ihmal (kelalaian). Karena yang diampuni adalah dosa atau hukuman pidana, bukan hukuman dhaman. Hal inilah yang menjadi perhatian para fuqaha'. Seorang faqih Sadru al-Syari'ah menyebutkan bahwa alkhatha' adalah apabila seseorang mengerjakan suatu perbuatan, tetapi perbuatan itu sendiri tidak diniati secara sempurna. Misalnya, orang menembak hewan buruan namun pelurunya nyasar mengenai seseorang sehingga tewas. Di sini terdapat niat atau al-qasdu yang tidak sempurna. Sehubungan dengan ini si pemburu tidak dapat dikenakan qisas karena hukuman ini diperuntukkan bagi pelaku pidana penuh. Atas dasar ini, ia tidak dapat dikenakan kepada orang $m a$ 'zur (orang yang dimaafkan). Namun 'uzur ini terkait dengan hakhak hamba sehingga kategori dhamannya adalah dhaman al-'udwan.

\section{MACAM-MACAM КНАTHA' DAN DARAR}

Secara teoritis khata' dapat berupa meninggalkan kewajiban yang ditetapkan oleh syariah. Misalnya, seorang ibu meninggalkan anaknya sehingga jatuh. Khata' juga dapat dalam bentuk melakukan perbuatan yang haram. Misalnya, memberikan kesaksian palsu, merampasharta orang lain, merusak atau menyebabkan rusaknya harta. 
Dhaman tidak akan berlaku kalau tidak ada unsur khatha'. Dan khatha' tidak akan ada kalau seseorang melakukan suatu perbuatan yang diijinkan oleh syariah (hukum).

Sedangkan darar sendiri ada tiga macam, yaitu darar yang berkaitan dengan kehartabendaan; darar yang berkaitan dengan fisik; dan darar yang berkaitan dengan kehormatan dan nama baik seseorang atau lembaga. Yang terakhir ini disebut dengan darar adabi. Menjaga dan melindungi kehormatan dan nama baik masuk dalam kategori al-masalih al-daruriyah atau kemaslahatan primer.

Namun dari aspek lain, darar dibagi menjadi dua, yaitu, pertama, darar al-yasir (kerugian ringan). Para fuqaha' pada umumnya berpendapat tidak ada dhaman terhadap darar ini. Menuruthemat penulis, permasalahan ganti rugi terhadap darar yasir bersifat kondisional. Kedua, darar fakhisy (kerugian berat).

Beberapa kaidah yang berkaitan dengan darar adalah:

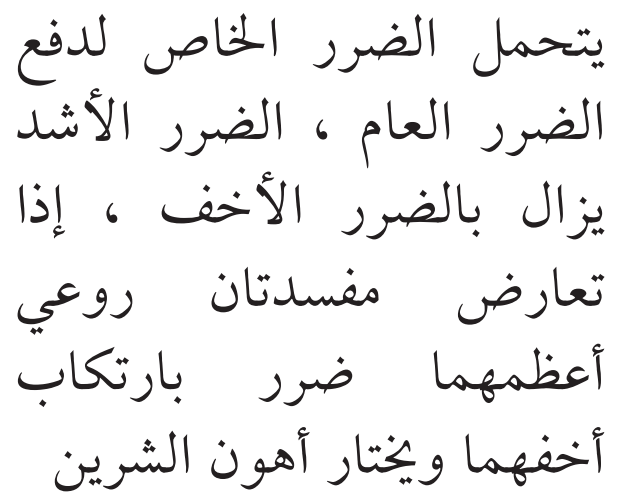

Sementara kerusakan terhadap harta benda (darar maliyah) dapat digolongkan menjadi kerusakan terhadap benda bergerak (manqulat), benda tidak bergerak ('iqarat), dan jasa (al-manafi'). ${ }^{19}$

Para fuqaha' sepakat atas dhaman terhadap kerusakan benda bergerak (karena merampas barang, merusak atau menguranginya, mengubah bentuk barang atau mengeksploitasi pemanfaatannya). Sehubungan dengan dhaman barang-barang bergerak terdapat dua syarat:

Pertama, maliyatu al-manqul (barang bergerak itu betul-betul harta secara syara'). Al-manqulat (bentuk jamak dari al-manqul) yang kehartaannya tidak diakui oleh syara' tidak dapat dilakukan ganti rugi terhadapnya. Itulah sebabnya tidak ada dhaman dengan merusak bangkai, kulit bangkai, darah dan lainlain yang pemanfaatannya dilarang oleh syara'. Juga yang tidak dapat dilakukan dhaman terhadapnya adalah al-mubahat al-'âmmah (hak-hak umum) yaitu al-kala' (rumput), al-ma' (air) dan al-nâr (api). Itulah sebabnya jika ada seseorang menimba sumur orang lain sampai kering, tidak dikenakan dhaman. Sebab pemilik sumur, bukan berarti memiliki air, berbeda kalau merampas air dari wadah yang lain. Hukum al-kala' (kecuali kalau dipelihara dan ditanam), dan al-nâr sama dengan hukum al-mâ'.

Kedua, tuqawwimu al-manqul (barang tersebut mengandung nilai ekonomis). al-Taqawwum menurut Ibn Nujaim dapat ditetapkan berdasarkan

${ }^{19}$ Lihat Ibrahim Fadil al-Dabbo, Dhaman alManafi' dirasah muqaranah fi al-fiqh al-islami wa alqanun al-madani, Amman, Beirut: Dar al-Bayariq, Dar 'Ammar, Cet. I, 1417 H/ 1997. 
dua hal, yaitu adanya unsur kehartaan (al-maliyah) dalam suatu barang, dan barang tersebut boleh dimanfaatkan menurut syara'.

Adapun barang-barang tetap (al-iqââat, immovable property), para fuqaha' bersepakat wajibnya dhaman terhadapnya apabila merusak keseluruhan, sebagian atau merugikan pemiliknya. Berbeda dengan manâfi' terdapat perbedaan pendapat yang berkaitandengandhamanterhadapnya. Perbedaan ini sebagai konsekuensi dari silang pendapat yang terjadi antara fuqaha tentang status kehartaan almanafi' (maliyatu al-manafi'). Fuqaha' Hanafiyah terutama generasi awal tidak menetapkan dhaman terhadap al-manafi', karena wujudnya yang abstrak, sehingga ia tidak termasuk harta. Pendapat ini berbeda dengan pendapat mayoritas fuqaha dari berbagai mazhab, termasuk Syiah Imamiyah, menurut mereka dhaman terhadap al-manafi' sesuatu yang wajib.

Argumentasi fuqaha' Ahnaf antara lain bahwa al-manafi' tidak mengandungnilaiekonomis. Statusnya sama dengan khamar dan bangkai. Artinya, al-itlâf tidak tergambar pada al-manâfi' mengingat sifatnya yang abstrak. Pendapat ini oleh fuqaha' Hanafiyah generasi mutaakhkhirin dianggap lemah, sehingga mereka mengevaluasi pendapat tersebut dan mengemukakan bahwa al-manâfi' adalah bagian dari al-mal (harta).

Adapun darar badaniyah meliputi jiwa, anggota badan, atau hilangnya fungsi salah satu anggota badan.
Misalnya, hilangnya pendengaran dan penglihatan. Terhadap semua kasus yang berkaitan dengan kerugian fisik seluruh atau sebagiannya, menurut para fuqaha' berlaku hukum dhaman terhadapnya.

\section{E. MENAKAR GANTI RUGI}

Tujuan dari pada dhaman adalah untuk memberikan ganti rugi pada korban dan menghilangkan kerugian yang diderita (raf'u al-darar wa izalatuha). Hal ini mencakup dua hal. Pertama ganti rugi terhadap kerugian yang berhubungan dengan jiwa, kehormatan, dan nama baik seseorang. Kedua, ganti rugi terhadap kerugian yang berkaitan dengan harta benda.

Ganti rugi terhadap kerugian yang berhubungan dengan jiwa disebut jawabir al-dharar al-badaniyah mencakup kehilanganjiwa, kehilangan anggota badan, atau fungsi keduanya. Jawabir model ini oleh para fuqaha' disebut dengan diyat (ganti rugi pembunuhan), ursy al-muqaddarah wa gairu al-muqaddarah (denda luka yang sudah ditetapkan di dalam nas). Ganti rugi model ini sering disebut hukumatu 'adl karena ukuran kualitas dan kuantitasnya diserahkan kepada otoritas peradilan yang adil.

Adapun ganti rugi yang berkaitan dengan harta (jawabir aldarar al-maliyah) seperti perampasan, perusakan terhadap barang atau manfaatnya mencakup dua hal yaitu:

1. Jawabir naqdiyah yaitu ganti rugi dengan mengembalikan nilai jual barang (al-qimah). 
2. Jawabir 'ainiyah, yaitu ganti rugi dengan mengembalikan barang itu sendiri, atau menggantinya dengan barang yang sama dalam kasus-kasus perampasan dan penguasaan terhadap harta orang lain secara tidak legal.

Adapun hitungan atau perkiraan (al-taqdir) ganti rugi bisa mengacu pada beberapa model berikut. Pertama, perhitungan ganti rugi berdasarkan kesepakatan (al-taqdir al-ittifaqi). Kedua, penggantian ganti rugi yang dilakukan oleh hakim (altaqdir al-qadai) yang mengacu pada ijtihad dan pendapatnya. Dan, ketiga, penghitungan ganti rugi sesuai dengan yang ditetapkan oleh pembuat undang-undang (al-taqdir al-syar'i).

Hitungan dan perkiraan ganti rugi tersebut berasaskan pada beberapa hal.

1. Ganti rugi tidak dimaksudkan untuk memperkaya pihak yang dirugikan, menolongnya, atau memberikan tabarru' terhadapnya.

Namun, dimaksudkan untuk mengembalikan keadaannya seperti sebelum terjadi kerugian-dengan catatan jika hal itu memungkinkan.

2. Ganti rugi dibebankan kepada pihak yang mengakibatkan darar secara langsung. Adapun darar tidak langsung yang tidak dapat dinisbatkan kepada perbuatan muta'addi tidak dapat dikenakan ganti rugi.

3. Hitungan dan perkiraan ganti rugi disesuaikan dengan tingkat darar yang ada, tidak lebih dan juga tidak kurang. Menyimpang dari prinsip ini dikategorikan "aklu amwalinnas bi al-bathil (makan harta orang lain secara batil). Kecuali dalam kasus di mana tingkat ta'addi-nya sangat tinggi, ganti rugi perlu dilipatgandakan agar pelaku menjadi jera.

Bila dilihat dari berat ringannya ganti rugi, para fuqaha' membaginya menjadidua macam. Pertama,kerugian ringan (jawabir mukhaf-fafah) yang diukur berdasarkan tingkat kerugian (darar) yang diderita pihak korban. Kedua, kerugian berat (jawabir mughallazah). Jawabir mukhaf-fafah terlihat pada kasus-kasus dalam kategori khatha'. Sedangkan jawabir mugallazah terlihat pada kasuskasus syibhu al-'amad (perbuatan semi sengaja). Pelipatgandaan ganti rugi dikenakan kepada mereka yang mengambil harta orang lain dan membelanjakannya untuk memperkaya diri sendiri. Tujuan dari tagliz (pemberatan dengan pelipatgandaan kerugian) adalah zijru al-muta'addi (membuat pelaku agar menjadi jera) tidak mengulangi perbuatan yang melawan hukum. Kendati demikian perbedaan antara al-'uqubah dengan dhaman selalu ada, setidaknya dapat diamati sebagai berikut:

1. Al-qatl syibhu al-'amad (pembunuhan semi sengaja). Sisi tagliz dalam kasus pembunuhan ini adalah tingginya umur unta yang dijadikan sebagai diyat 
wajib. Hal ini berdasarkan hadis riwayat Abdullah Ibn Amr bahwa Rasulullah bersabda ${ }^{20}$ :

آلا إن في قتيل عمد الخطأ ' قتيل السوط

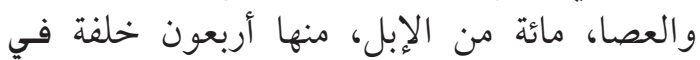
بطونها أولادها (bahwa dalam kasus pembunuhan semi sengaja yaitu pembunuhan dengan cemeti dan tongkat, dendanya seratus unta, 40 di antaranya sedang mengandung). Hadis yang searti dengan itu juga diriwayatkan oleh Amr Ibn Syu'aib bahwa seseorang yang bernama Qatadah melempar anaknya dengan pedang sampai tewas. Karena itu, diyat yang dibebankan kepadanya adalah 30 ekor unta kategori hiqqah (umur 3 tahun masuk tahun ke 4), 30 unta lagi kategori jiz'ah (umur 4 tahun masuk tahun ke 5), dan 30 ekor lagi kategori khilfah (unta yang sedang mengandung).

2. Mengambil harta orang lain yang sulit diletakkan pada wadah tertentu atau dijaga sepanjang waktu. Diriwayatkan dari Amr Ibn Syu'aib dari ayah dan neneknya berkata: "Rasulullah pernah ditanya tentang buah-buahan yang masih menggantung di pohonnya. Lalu beliau bersabda:

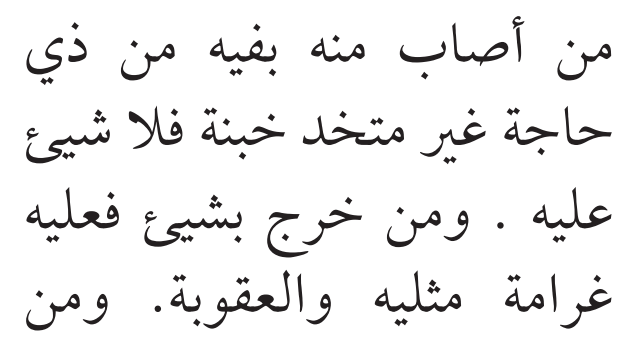

${ }^{20}$ Hadis dan takhrij-nya dapat dilihat dalam Nail al-Authar oleh al-Syaukani, hal. 7/ 167.

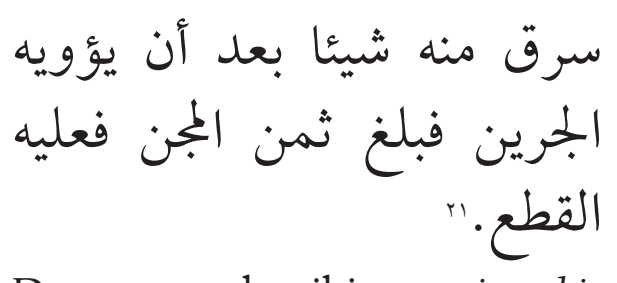

Dengan demikian jawabir mugallazah tidak hanya pada luka-luka fisik, melainkan juga pada kerugian harta dalam situsi-situasi yang memerlukan "pemberatan terdakwa" seperi ingin memperkaya diri dengan cara merugikan orang lain. Fenomena ini sekaligus memberikan keleluasaan hakim dalam menghitung dan memperkirakan kualitas dan kuantitas ganti rugi.

\section{F. PRINSIP UMUM PENETAPAN GANTI RUGI}

Penggunaan istilah al-jabr oleh para fuqaha' dalam konteks dhaman yang dihubungkan dengan darar masih mengandung ambiguitas. Karena makna darar sangat beragam mengikuti konteksnya. Misalnya, al-jibr al-kamil (ganti rugi penuh) bertujuan untuk menetapkan ganti rugi yang harus ditanggung oleh pihak pelaku (al-mutadarrir). Darar dalam konteks ini mencakup darar maliyah, darar badaniyah, dan darar adabiyah. Standarisasi jibru al-kamil bersifat kondisional, tergantung pengadilan dan usaha cerdas hakim. Karena betapa sulitnya mengukur rasa sakit yang bersifat psikis dibandingkan kerugian lain yang bersifat material. Dengan kata lain, rasa keadilan yang didambakan oleh para pencari

${ }^{21}$ Lihat juga beberapa hadis lain yang $\mathrm{s}$ makna dalam Nail al-Authar oleh al-Syaukani, hal. $7 / 301$ dst. 
keadilan sangat ditentukan oleh sikap, kecermatan, dan keadilan hakim itu sendiri.

Dalam menetapkan ganti rugi, setidaknya harus didasarkan pada empat prinsip. Pertama, prinsip al-yusr (memudahkan) dalam menghitung dan mengukur ganti rugi tersebut untuk menghindari proses dan prosudur yang panjang di pengadilan agar para pencari keadilan tidak terlalu lama menunggu haknya.

Kedua, konsisten. Artinya, terdapat keseragaman kualitas dan kuantitas ganti rugi dalam kasus yang sama pula.

Ketiga, menyamakan (almusawat) antara semua penduduk dalam menerima ganti rugi. Misalnya, jangan sampai ada pembedaan antara petani dengan pengusaha untuk ganti rugi kasus yang sama, karena prinsip dalam menetapkan darar bukan mempertimbangkan strata sosial atau kemampuan finansial.

Dan keempat, harus terlebih dahulu mengidentifikasi dan menetapkan tingkat keterlibatan para pelaku. Karena hal ini akan menentukan kualitas ganti rugi yang akan dibebankan kepada mereka.

\section{G. PRINSIP AL-MISLI DALAM MENETAPKAN GANTI RUGI}

Prinsip persamaan (mabda' almisliyah) dalam ganti rugi ditetapkan berdasarkan nas syariah antara lain firman Allah wajazau saiatin saiatun misluha. Disebut dengan istilah aluqubah atau al-jaza' semata-mata dalam konteks al-musyakalah/al- mumasalah (persamaan), dan juga untuk mengingatkan si pelaku agar menjadi jera. Prinsip al-mumasalah juga diperkuat oleh ayat fa mani'tada 'alaikum fa'tadu 'alahi bi misli ma i'tada 'alaikum. Untuk membantu kita dalam menafsirkan ayat ini, perlu kiranya mengutip perkataan al-Zaila'i, seorang fuqaha' Hanafi, wa dhaman al-udawan masyruthun bi al-mumasalah bi al-nassi wa al-ijma'. Wasummiya dhaman al-muqabil i'tidaan bi thariq almuqabalah li fi'li al-i'tida' awu al-idhrar majazan la haqiqatan, li anna al-majazat awu dhaman la yakun saiyiah wala ta'ddiyan. ${ }^{22}$ Inti dari pernyataan alZaila’i bahwa ganti rugi pelanggaran disyaratkan harus sama berdasarkan nas dan ijma', sedangkan penamaan dhaman berdasarkan pelanggaran dalam konteks majazi, bukan pada makna hakikinya, karena ganti rugi menurut makna majazinya bukanlah sesuatu yang buruk atau merupakan suatu pelanggaran.

Menghitung ganti rugi mengacu pada kaidah kesepadanan (al-misli) dengan mempertimbangkan metode syari' dalam menetapkan al-misli, alqimah dan ujratu al-misli terhadap ganti rugi al-mal. Namun, manakala kaidah al-misli sulit diterapkan dalam kasuskasus luka fisik (al-isabat al-badaniyah), karena luka fisik, sesungguhnya, tidak mungkin sepadan dengan ganti rugi dalam bentuk uang, maka syari' menetapkan ukuran-ukuran tertentu yang dapat direalisasikan yaitu al-

${ }^{22}$ Usman Ibn Ali al-Zaila'i, Tabyin al-haqoiq Syarh Kanzu al-Daqaiq, Kairo: Dar al-Kitab al-Islami, Cet. II, 1990, hal. V: 223. 
jawabir al-muqaddarah misalnya diyat (denda pembunuhan), al-urusy (denda luka), al-aqilah (denda pembunuhan kolektif), dan lain-lain. Hal ini kemudian oleh para fuqaha' disebut al-mumasalah al-hukmiyah.

\section{H. PENCEMARAN NAMA BAIK (IZA' AL-MUSLIM FI SUM'ATIHI)}

Untuk melindungi kehormatan seseorang, syariah memulai dari masalah yang sederhana. Misalnya, larangan menuduh seseorang melakukan zina (al-qazf), larangan saling mencela dan memberi julukan jelek (al-tanabuz bi al-alqaf) atau menafikan keturunan (nafyu alnasab). Hal ini sesuai surat al-Hujarat ayat 11-12. Demikian pula dalam Surat al-Nur ayat 4-5. Sedang di dalam hadis disebutkan, al-muslim man salimal muslimun min lisanihi wayadih (seseorang baru dikatakan muslim apabila menyelamatkan umat Islam dari gangguan ucapan dan prilakunya).

Para fuqaha' kemudian merumuskan masalah pencemaran nama baik dalam bingkai al-maqasid al-khamsah li al-syariah (lima kemaslahatan), yaitu menjaga agama, jiwa, moral, akal, dan harta. Hanya saja, para fuqaha' lebih banyak fokus pada hal-hal yang terkait dengan al'ardh dalam pengertian yang sangat sempit dengan menjelaskan hukuman pelaku zina, hukuman bagi penuduh berbuat zina. Tegasnya, para fuqaha' lebih asyik menjelaskan hukumhukum yang berkaitan dengan zina (alqazf), atau hukum lain yang berkaitan dengan kehormatan keluarga.
Al-Qur'an mengharamkan apa pun bentuk perbuatan yang menyentuh kehormatan muslim. Dalam surat al-Nur ayat 4 dan 5, alQur'an mengharamkan qazf, zina, dan hukumannya. Sementara dalam ayat 11 dan 12 Surat al-Hujarat mengisyaratkan berbagai bentuk pelanggaran yang menyentuh kehormatan dalam pengertian yang lebih luas. Misalnya sukhriyah (pengejekan), al-lamz (mencela dan mengkritik dengan bahasa yang tidak etis), tanabuz bi al-qaaf (saling mencela dengan memberi julukan jelek), tajassus (memata-matai) dan al-gibah (umpatan).

Betapapun terbatasnya konsep perlindungan nama baik yang telah dirumuskan parafuqaha', namundapat diidentifikasi menjadi pelanggaran (al-ta'addiyat) terhadap nama baik seseorang yang meliputi tuduhan melakukan zina dan tuduhan terhadap selain zina yang dapat mengakibatkan pencemaran nama baik.

Oleh karena itu fungsi faqih termasuk hakim dalam hal ini adalah melakukan istimbath hukum sekaligus mengembangkan konsep perlindungan terhadap kehormatan. Tegasnya, mereka harus mewujudkan konsep tersebut berdasarkan keumuman konsep syariah dan maqasid-nya.

\section{HAL-HAL YANG MENAFIKAN DHAMAN}

Pada prinsipnya dhaman diberlakukan kepada siapapun yang menyebabkan kerugian pihak lain. 
Namun demikian, dhaman juga tidak dapat diberlakukan kalau terdapat halangan (al-mawani') atau alasan pembenar, antara lain:

1. Pemusnahan barang secara legal. Misalnya, khamar atau barang-barang sejenis tidak dapat diberlakukan ganti rugi terhadap muslim baik pribadi mapun kolektif. Karena khamar dan babi adalah harta yang pemanfaatannya dilarang oleh syariah (mal gairu mutaqawwim). Memusnahkan harta jenis ini termasuk suatu kewajiban syariah. Pendapat ini dikemukakan oleh mayoritas ulama. Hanya saja ulama Syafi'iyah dan Hanabilah menambahkan khamar dan babi yang dimiliki kaum zimmi juga harus dimusnahkan.

2. Pemusnahan terhadap harta benda yang dilakukan oleh seseorang semata-mata karena melaksanakan tugas (perintah dalam konteks ketaatan) seperti para pembantu hakim, tidak dibebani ganti rugi. Berbeda, misalnya perintah itu dalam konteks maksiat, maka ganti rugi menjadi suatu kewajiban.

3. Apabila sesuatu yang diperintah tergolong boleh dilakukan (ja'iz al-fi'l) serta dikerjakan atas dasar ketaatan terhadap perintahketaatan seorang pegawai terhadap atasan, misalnyamaka dalam hal ini perbuatan orang yang diperintah sama dengan perbuatan orang yang memberi perintah. Dengan demikian ganti rugi dibebankan kepada yang memberi perintah, dengan catatan jika perbuatan tersebut memang benar-benar mengharuskan ganti rugi.

4. Melakukan sesuatu yang merugikan orang lain dalam keadaan darurat. Misalnya melakukan perusakan terhadap harta benda orang lain, dalam keadaan terancam baik jiwa maupun hartanya oleh orang lain atau hewan, tidak dibebankan ganti rugi. Tentu saja terikat dengan syaratsyarat tertentu. Misalnya mencegah terjadinya suatu kerugian dengan melakukan sesuatu yang merugikan pihak lain harus bersifat tiba-tiba dan seketika. Tanpa direncanakan sebelumnya.

5. Keadaan darurat (halat aldarurah). Apabila seseorang dalam keadaan lapar atau haus yang dapat mengakibatkan kematiannya. Untuk mencegah kematian tersebut diperbolehkan makan atau minum milik orang lain, dengan syarat tidak melebihi kebutuhan. Dalam keadaan seperti ini kewajiban ganti rugi menjadi gugur, tetapi ia diwajibkan untuk membayar makanan dan minuman itu sebagai pengamalan dari kaidah:

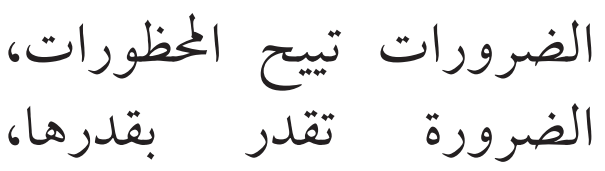




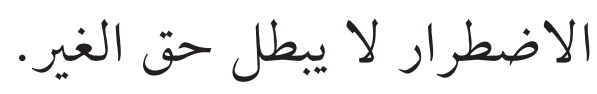

Pendapat tersebut disepakati oleh mazhab empat dan juga pendapat mazhab Zaidiyah.

1. Ada kerelaan dari pihak yang dirugikan. Jika seseorang memerintahkan oranglain untuk membuang bajunya ke laut, atau merusak rumahnya, ternyata perintah itu dilakukan, maka orang tersebut tidak dibebani ganti rugi. Sebab, perintah untuk melakukan hal tersebut, masih dalam batas wewenangnya. Lagipula, yang melakukan perintah tersebut tidak termasuk pelaku pelanggaran (muta'addi).

2. Apabila pembebanan ganti rugi itu tidak berguna ('adamu alfaidah fi al-tadhmin). Jika kaum muslim memusnahkan harta benda kaum pemberontak (al-bugat), atau sebaliknya albugat memusnahkan harta benda kaum muslim, masingmasing tidak dapat dibebani ganti rugi. Sebab, pembebanan ganti rugi kepada mereka tidak berguna. Umat Islam tidak boleh menanggung ganti rugi terhadap harta benda orang-orang bugat. Sebaliknya orang muslim pun tidak dapat memberlakukan ganti rugi terhadap kaum bugat mengingattidakadakewenangan pemerintah muslim terhadap mereka. $^{23}$

${ }^{23}$ Jami' al-Fushulain, hal. 2/78, Ibn Abidin, Raddu al-Mukhtar ' ala al-Durri al-Mukhtar, Beirut: Dar al-Kutub al-'ilmiyah, Cet. I, 1415H/1994M, hal. 5/140, Muhammad Ibn Ahmad al-Dasuqi, Hasyi-

\section{J. PERUBAHAN STATUS YADU AMANAH MENJADI YADU DHAMANAH}

Tidak terdapat perbedaan antara para fuqaha' bahwa yad al-wadi' (orang yang menerima titipan), almusta'jir (penyewa), al-mudarib (pelaku usaha), al-syarik (mitra usaha), al-rasul (utusan), al-ajir al-khas, wakil sukarela, wali, wasi, al-multaqith atau orang yang menemukan dan memungut barang yang bertujuan untuk memperkenalkan barang adalah yadu amanah. Mereka tidak dibebani ganti rugi jika terjadi kerusakan barang pada saat berada dalam penguasaan mereka, kecuali kalau melakukan pelanggaran dan kecerobohan ( $t a^{\prime} a d d i$ dan tafrith). Karena tangan-tangan ini secara keseluruhan tergolong penolong (al-irfaq wa al-ma'unah). ${ }^{24}$ Jika tangan-tangan mereka dibebani ganti rugi, maka kepentingan publik akan terabaikan.

Aakan tetapi fuqaha' berbeda pendapat pada sebagian al-yad yang lain seperti yad al-musta'ir (peminjam barang), yad al-murtahin (penerima gadai), yad al-wakil dengan upah, yad ajir al-musytarak, dan yad sunna' (pembuat barang pada akad istisna'). Sebagian fuqaha' berpendapat bahwa tangan-tangan mereka termasuk tangan amanah sehingga kalau terjadi kerusakan barang tidak dibebani ganti rugi. Sedangkan fuqaha' yang lain berpendapat bahwa tangan-tangan

\footnotetext{
yah 'ala al-Syarh al-Kabir, Beirut: Dar al-Kutub al'ilmiyah, Cet.I, 1417 H/ 1996 M, hal.4/ 240.

${ }^{24}$ Al-Mawardi, al-Hawi, hal. 8/192, 394, 9/104, 10/385.
} 
mereka adalah yadu dhaman, artinya jika terjadi kerusakan pada barang pada saat dalam mpenguasaan mereka dibebani ganti rugi. ${ }^{25}$

Perbedaan pendapat tersebut muncul karena beberapa sebab. Pertama: Sebagian al-aidi (jamak dari al-yad) tersebut dari satu sisi memiliki kemiripan secara dominan dengan al-aidi al-aminah, sedang di sisi lain kemiripannya juga dominan dengan al-aidi al-daminah. Fuqaha yang mentarjih kemiripannya dengan al-aidi al-aminah menjadikannya bagian dari yad amanah sendiri, sebaliknya fuqaha' yang mentarjih kemiripannya dengan al-aidi al-daminah menjadikannya bagian dari al-yad al-daminah. ${ }^{26}$

$$
\text { Kedua sebagian fuqaha' }
$$

melakukan istihsan untuk menetapkan ganti rugi terhadap al-aidi al-aminah untuk mengantisipasi kerugian akibat kerusakan barang karena suatu kecerobohan dan kelalaian mereka. Ketiga terdapat perbedaan pendapat tentang subut-nya sejumlah nas yang berkaitan dengan al-aidi. Misalnya hadis: ليس على المستعير غير المغل ضمان dan

${ }^{25}$ Lihat referensi sejumlah figh klasik dalam Nazih Hammad, Qodoya Fiqhiyah Mu'asirah fi al-mal wa al-Iqtisad, Damaskus: Dar al-Qalam, Cet. I, 1421 H/ 2001 M, hal. 370

${ }^{26}$ Lihat al-Muqaddimat al-mumahhidat, hal. 2/246, 368, al-Mawardi, al-Hawi, ha. 8/191, 9/254, al-Qurafi, al-Furuq, hal. 2/207, Ibn Rajab, alQawa'id, hal. 60, Kasyfu al-Qina', hal. 92, al-Zakhirah, hal. $8 / 112$.

${ }^{27}$ Diriwayatkan oleh Daral-quthni dan alBaihaqi dari hadis 'Amr ibn Syu'aib dari ayahnya dan kakeknya. Daral-quthni menda'ifkan hadis ini. Ibn Hajar berkata: dalam isnadnya ada dua orang yang da'if. Lihat Ibn Hajar al-Asqalani, al-Talkhis al-Habir fi Takhrij Ahadis al-Rafi'I al-Kabir, Mesir: Syarikat al-Thiba'ah al-Fanniyah, $1384 \mathrm{H}$, hal. 3/97, dan Syaukani, Nail al-Authar, hal. 5/296.
أد الأمانة إلى dan لى اليد ما أخذت حتى تؤديه 28

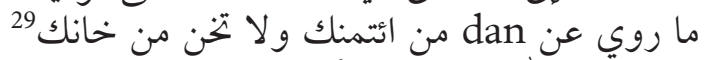

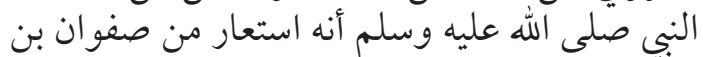

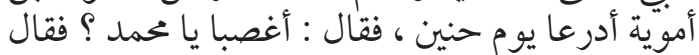
30": "بل عارية مضمونة

Terlepas dari silang pendapat tersebut status yadu amanah dapat berubah menjadi yadu dhamanah karena antara lain pertimbagan 'urf atau tradisi kolektif yang berlaku di tengah masyarakat. Pendapat ini umum di kalangan fuqaha' Hanafiyah dan Malikiyah. Mereka kemudian mengemukakan kaidah fiqh yang berkaitan dengan al-'urf yaitu:
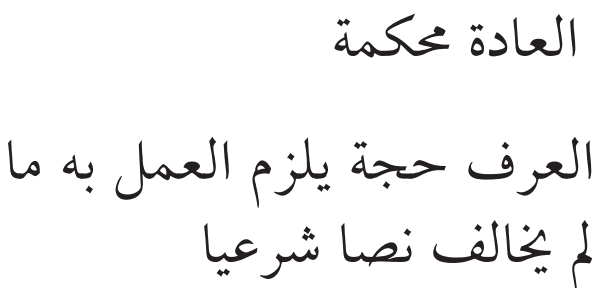

Contoh konkret mengenai masalah tersebut dapat ditemukan dalam fiqh mazhab Hanbali yang mengatakanbahwaparahurras(tukang jaga, satpam untuk masa sekarang) barang tidak dapat dibebankan ganti rugi. Sebab mereka tergolong yadu amanah. Namun demikian, seperti dikemukakan oleh penulis Kasyfu al-

${ }^{28}$ Diriwayatkan oleh Abu Daud, Tirmizi, Ibn majah dan lain-lain. Hadis ini juga da'if. Lihat Ibn Hajar, al-Talkhis, hal. $3 / 353$ dan Syaukani, Nail alAuthar, hal 5/298.

${ }^{29}$ Diriwayatkan oleh Abu Daud, Tirmizi, alDaromi, dan lain-lain, kendati diakui sebagai hadis hasan oleh Tirmizi, namun Syafi'i mengatakan bahwa hadis ini tidak sabit.

${ }^{30}$ Diriwayatkan oleh Abu Daud, Tirmizi, Nasa'i, Ibn Majah dan lain-lain. Sebagian ulama mensahihkan hadis ini. Tetapi menurut Syaukani jalan hadis ini dianggap cacat oleh Ibn Hazm dan Ibn Qattan. Lihat Ibn Hajar al-Talkhis, hal. 3/52. 
Qina', ${ }^{31}$ para hurras tersebut sewaktuwaktu dapat dibebani ganti rugi berdasarkan pertimbangan al-'urf: Beliau mengatakan:

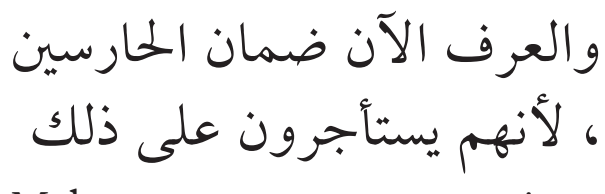

Makna yang sama juga dikemukakan oleh Ibn Nujaim, seorang faqih penganut mazhab Hanafi, ketika menjawab pertanyaan dan mengomentari kaidah: المعروف كالمشروط. Beliau mengatakan:

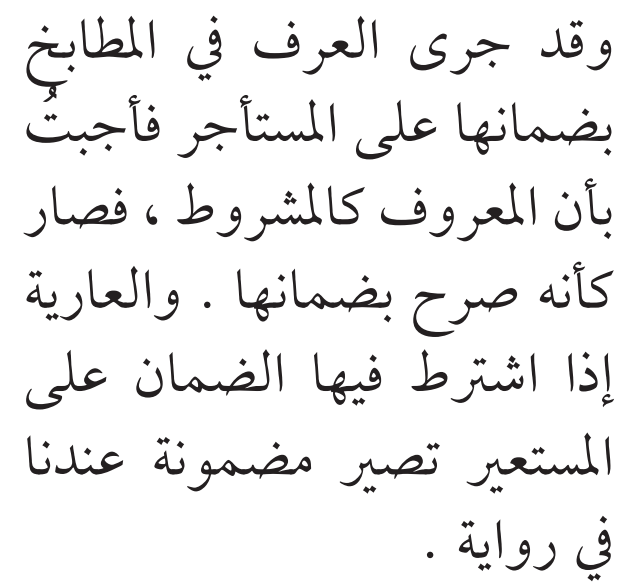

Jadi, menurut Ibn Nujaim, para pekerja dan peminjam barang dikenakan ganti rugi jika terjadi kerusakan akibat kecerobohan atau kelalaian.

Selain faktor 'urf, unsur ta'addi (perlakuan yang melampaui wewenang baik secara syara' maupun 'urf) juga dapat menyebabkan ganti rugi bagi yad amanah. Hal ini menjadi kesepakatan para fuqaha' seperti ta'addi yang dilakukan oleh al-wadi' (yang diberi kepercayaan memegang titipan) terhadap al-wadi'ah (titipan)

${ }^{31}$ Al-Buhuti, Kasy-Syaf Al-Qina', Makkah: Mathba'ah Al-Hukumah . 1394 H, hal. 2 / 69. dengan merusak atau memanfaatkan tanpa seizin pemiliknya. Atau juga ta'addi yang dilakukan oleh mudharib (yang melakukan usaha dalam akad mudarabah) ketika mengerjakan sesuatu di luar kontrak dengan sahib al-mal (pemilik modal). Seperti juga al-ta'addi yang dilakukan oleh alajir (tenaga sewaan/orang upahan) dengan tidak mengindahkan perintah al-musta'jir (orang yang menyewa tenaga), atau juga tindakan wakil (wakil) yang melampaui wewenang yang didelegasikan oleh al-muwakkil (pihak yang diwakili). Mereka ini terkena kewajiban dhaman karena sebagai pelaku langsung (mubasyir) yang mengakibatkan kerusakan, atau penyebab rusaknya barang secara zalim dan adanya unsur permusuhan.

Jika terjadi perselisihan antara al-amin dengan sahib al-mal tentang prilaku ta'addi ini, maka penyelesaiannya diserahkan kepada ahli atau orang yang memiliki kompetensi untuk itu. Solusi seperti ini sesuai dengan petunjuk Majallatu al-Ahkam al-Syar'iyah 'ala Mazhabi Ahmad $^{32}$.

Al-tafrith menurut bahasa al-taqshir dan al-tadhyi' (kelalain, kealpaan, kesembronoan). Sedangkan al-Ifrath bermakna al-israf wa mujawazatu al-had (melampaui batas, pemborosan). Menurut al-Jurjani ${ }^{33}$ alifrath digunakan pada kesewenangan yang berlebihan melampaui porsi yang normal (tajawazu al-had min janib al-ziyadah wa al-

${ }^{32}$ Al-Qori, Majallatu Al-Ahkam Al-'Adliyah 'Ala Mazhabi Ahmad, Jedah: Tihamah, $1401 \mathrm{H}$.

${ }^{33}$ Syarif Al-Jurjani, Al-Ta'rifat, Al-Dar Al-T nisiyah Li Al-Nasyr, 1971, Hal. 43. 
kamal). Sedangkan al-tafrith digunakan pada sikap minimalis yang tidak proporsional (tajawazu al-had min jihat al-nuqshon wa altaqshir).

Para fuqaha' sepakat bahwa yadu amanah dapat berubah status menjadi yadu dhamanah karena perilaku tafrith. Hal ini bisa terjadi pada mudharib, wadi', dan musta'jir. Standar tafrith yang mengharuskan dhaman itu ditakar dengan al-urf. Sedangkan tatawwu'ul amin bi iltizam ad-dhaman ba'da al-'aqdi (kesanggupan dan kerelaan dari al-amin secara suka rela untuk melakukan ganti rugi setelah akad), menurut mazhab Maliki termasuk dalam kategori tabarru'.

Selain itu, pertimbangan maslahah juga dapat memposisikan yadu amanah menjadi yadu dhamanah. Tentunya kemaslahatan pihak yang dikorbankan. Terakhir adalah altuhmah. Maksudnya, terdapat dugaan kuat bahwa terjadi kebohongan dari al-amin yang menyatakan bahwa kerusakan barang bukan karena kelalaian atau kecerobohannya, melainkan faktor lain di luar kemampuannya. Klaim seperti ini sangat mungkin dilakukan oleh mereka yang berstatus yadu amanah yang tidak menyadari tanggung jawabnya. Atas dasar ini ganti rugi tetap diberlakukan kepada mereka.

Demikian pula yadu amanah berubah menjadi yadu dhamanah karena syarat-syarat yang ditetapkan secara sepihak (isytirath dhaman 'ala alamin), namun mendapat persetujuan dari pihak yadu amanah baik itu mudharib, musta'jir, wadi', wakil, syarik atau lainnya. Tetang masalah ini terdapat silang pendapat di antara para fuqaha'. Pendapat pertama, syarat yang ditetapkan tersebut adalah batal karena tidak sejalan dengan karakteristik akad yang berstatus amanah. Pendapat ini dikemukakan oleh fuqaha' Hanafiyah, Syafi'iyah, Malikiyah, dan fuqaha' Hanabilah dalam salah satu pendapat mereka yang populer. Pendapat tersebut juga dikemukakan oleh al-Sauri, Auza'i, Ishaq, Nakha'i, dan Ibn al-Munzir. Atas dasar pendapat ini muncul kaidah fiqh dalam mazhab Hanafi, yaitu

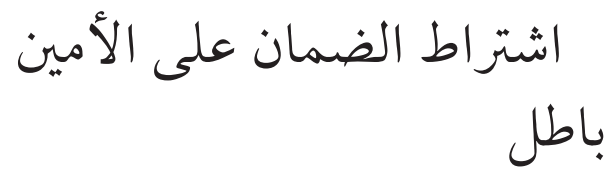

Pendapat kedua, menetapkan syarat karena faktor yang mengkhawatirkan pemilik modal misalnya, dapat dibenarkan dan diberlakukan jika sesuatu yang dikhawatirkanitu dalam kenyataannya merusak barang sehingga mengakibatkan kerugian pada pemilik modal. Pendapat ini dikemukakan oleh Mutharrif dari mazhab Maliki.

Pendapat ketiga, syarat tersebut sahih dan mengikat. Pendapat ini dikemukakan oleh Qatadah, Usman alButtiy, Ubaidillah ibn Hasan al-Anbari, Dawud al-Zahiri dan Ahmad dalam salah satu riwayatnya. Walaupun pendapat ini kurang populer di kalangan fuqaha' Malikiyah, dan pendapat yang tergolong lemah dalam mazhab Hanafi, namun pendapat ini mendapat dukungan dari Imam Syaukani, beliau mengatakan: 


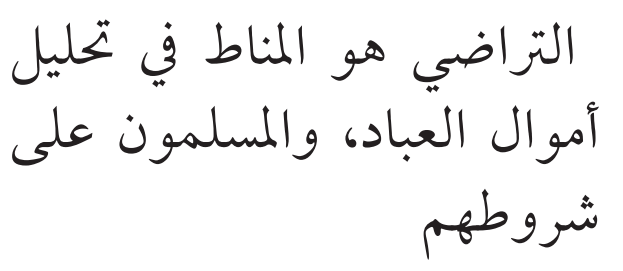

\section{K. PENUTUP}

Ide dhaman dalam hukum Islam bersamaan dengan datangnya sumber hukum Islam sendiri. Sejumlah ayat dan hadis secara eksplisit telah mengisyaratkan dhaman ini. Lalu kemudian dikembangkan oleh para fuqaha' dalam kontek perdata dan pidana. Dalam konteks perdata para fuqaha, khususnya al-Qurofi dan al-'Iz Ibn Abdi Salam menggunakan istilah al-zawajir. Sedangkan dalam kontek pidana mereka menggunakan istilah al-zawajir. Adapun istilah al-masuliyah baru banyak ditemukan dalam fiqhfiqh karya ahli hukum Islam modern.

Secara garis besar dhaman muncul karena darar badaniyah, darar maliyah dan darar sangat mungkin terjadi di luar fisik dan harta, seperti pencemaran nama baik. Tetapi terdapat dararyang kualifikasinya tidak mudah dinominalkan dengan ganti rugi dalam bentuk uang misalnya. Karena itu berapa jumlah ganti rugi yang harus dibayarkan selain yang tidak ditetapkan berdasarkan nas. Persoalan ini kembali kepada al-'urf yang berlaku di masyarakat. Karena itu besarnya ganti rugi dapat ditetapkan berdasarkan kesepakatan para pihak. Jika cara ini sulit dilakukan maka besarnya ganti rugi ditetapkan berdasarkan ketetapan dari pembuat undang-undang. Namun demikian seorang hakim punya wewenang untuk menetapkan nominal ganti rugi asal sesuai dengan prinsipprinsip penetapan ganti rugi dan tidak bertentangan dengan rasa keadilan.

\section{DAFTAR PUSTAKA}

Al-Quran al-Karim

Ahmad Siraj, Muhammad, Dhaman al-'Udwan fi al-Figh al-Islami (Dirâsah Fiqhiyah Muqâranah bi ahkâm al-masuliyah al-Taqshiriyah fi al-qanun), al-Muassasah alJami'iyyah li al-Dirâsat wa alNasyr wa al-Tauzi'.

Atasi, Syarah Majallatu al-Ahkam alAdliyah, dicetak di Hims Suriah, $1352 \mathrm{H}$.

Al-Bagdadi, Majma' al-Dhamanat, Mesir: al-Khairiyah, $1388 \mathrm{H}$.

Al-Buhuti, Kasy-syaf al-qina', Makkah: Mathba'ah al-Hukumah $1394 \mathrm{H}$.

Al-Dabbo, Ibrahim Fadil, Dhaman al-Manafi' dirasah muqaranah fi al-fiqh al-islami wa al-qanun almadani, Amman, Beirut: Dar al-Bayariq, Dar 'Ammar, Cet. I, 1417 H/ 1997.

Al-Dasuqi, Muhammad Ibn Ahmad, Hasyiyah 'ala al-Syarh al-Kabir, Beirut: Dar al-Kutub al-'ilmiyah, Cet.I, 1417 H/1996 M.

Al-Hamawy, Ahmad Ibn Muhammad, Gamzu 'Uyûni al-Basha'ir wa Syarah al-Asybâh wa al-Nâza'ir, Bairut: Dar al-Kutub al-iilmiah, Cet. 1405 H/1985 M.

Ibn Abidin, Raddu al-Mukhtar ' ala alDurri al-Mukhtar, Beirut: Dar 
al-Kutub al-ilmiyah, Cet. I, $1415 \mathrm{H} / 1994 \mathrm{M}$

Ibn Hajar al-Asqalani, al-Talkhis alHabirfi Takhrij Ahadis al-Rafi'I alKabir, Mesir: Syarikat al-Thiba'ah al-Fanniyah, $1384 \mathrm{H}$.

Ibn Rajab, Syihabuddin, al-Qawa'id alFiqhiyah, Kairo, 1392 H/ 1997 M Ibn Rusydal-Hafid, Bidayatal-Mujtahid, Beirut: Dar al-Kutub al-ilmiyah, Cet. I, 1418 H/ 1997 M.

Al-Jurjani, Syarif, al-Ta'rifat, al-Dar alTunisiyah li al-Nasyr, 1971.

Majduddin al-Fairuzabadi, al-Qamus al-Muhit, Kairo: Dar al-Hadis, tt.

Al-Mawardi, Ali Ibn Muhammad, alHawi al-Kabir Syarh Mukhtasar alMuzani, Beirut: Dar al-Kutub al'ilmiyah, Cet. I, 1414 H/ 1994 M

Qol'aji, Muhammad Ruwas dan Qunaibi, Hamid Sodiq, Mu'jam Lugat alFuqaha' "Arabi-Inklizi, Beirut: Dar'alNafa'is, Cet.II, 1408 H/ 1988 M.

Al-Fatlawi, Shahib 'Ubaid, Dhaman al'uyub watakhallafa al-muwasafat fi 'Uqud al-Bai', Amman: Maktabah Dar al-Saqofah li al-Nasyr wa altauzi’, Cet. I, 1417 H/ 1997 M.

Al-Qori, Majallatu al-Ahkam al-'Adliyah 'ala Mazhabi Ahmad, Jedah: Tihamah, $1401 \mathrm{H}$.
Al-Qurafi, Ahmad Ibn Idris, al-Furuq $f i$ Anwar al-Buruq fi Anwai al-Furuq, Mansyurat Muhammad Ali Baidhun, Beirut: Dar al-Kutub al'ilmiyah, Cet. I, 1418 H/ 1998 M.

Al-Sarakhsi, al-Mabsut, Mesir: alSa'adah, $1324 \mathrm{H}$.

Suyuthi, Jalaluddin, al-Asybah wa al-Naza'ir, Beirut: Muassasah al-Kutub alSaqofiyah, Cet. 1, 1415 H/1994 M.

Al-Syarbini, Muhammad Ibn Ahmad, Mugni al-Muhtaj, Beirut: Dar Kutub al-ilmiyah, Cet. I, $1415 \mathrm{H} / 1994 \mathrm{M}$.

Al-Syaukani, Nail al-Authar Syarh Muntaqa al-Akhbar, Mesir: Mustafa al-Babi al-Halabi, $1380 \mathrm{H}$.

Al-Zaila'i, Usman Ibn Ali, Tabyin alhaqoiq Syarh Kanzu al-Daqaiq, Kairo: Dar al-Kitab al-Islami, Cet. II, 1990.

Al-Zarkasyi, Badruddin, al-Mantsur fi al-Qawa'id, Dar al-Kuwait, Cet. II, $1405 \mathrm{H}$.

Al-Zarqa', Mustofa Ahmad, al-Madkhal al-Fiqhi al-'Am (al-Fiqh al-Islami fi Saubihi al-Jadid),Beirut: Dar alFikr, hal. 1032.

Al-Zuhaily, Wahbah, al-Mas'uliyah 'an Fi'li al-Gair, Damaskus: Dar alMuktabi, Cet. 1, 1416 H/1995 M. 